\title{
DE ACCOUNTANTSVERKLARING BIJ ONZEKERHEDEN
}

\author{
door Mr.J. M. van der Beek
}

Het Nederlands Instituut van Registeraccountants heeft in 1977 een meningsuiting uitgegeven: De Inhoud van de Accountantsverklaring bij de Jaarrekening van Ondernemingen met Continuiteitsproblemen. Het zou nuttig kunnen zijn eens naast elkaar te zetten de verschillende opvattingen in Nederland, de Verenigde Staten en het Verenigd Koninkrijk aangaande de rapportering door de accountant over jaarrekeningen van ondernemingen bij onzekerheden, waarvan het continuïteitsprobleem, zij het een meer voorkomende, verschijningsvorm is.

\section{Inleiding}

Een van de functies van het uitoefenen van het openbare accountantsberoep is het onderzoek naar de getrouwheid van de jaarrekening en, gebaseerd op dit onderzoek, het doen van een mededeling omtrent de uitkomst van dat onderzoek. Deze mededeling behelst het oordeel van de accountant over de al dan niet getrouwheid van de jaarrekening ofwel maakt kenbaar dat naar de mening van de accountant zodanige onzekerheden bestaan dat het hem niet mogelijk is tot een oordeel te geraken omtrent die getrouwheid zonder meer, noch omtrent die getrouwheid zonder daarbij te wijzen op die onzekerheden.

De opvattingen met betrekking tot de wijze waarop de accountant zich op dient te stellen bij aanwezigheid van onzekerheden zijn internationaal gezien verschil. lend. Een aantal van deze opvattingen, zoals die blijken uit vakliteratuur en uit. spraken van accountants-instituten in Nederland, de Verenigde Staten en het Ver. enigd Koninkrijk, wordt hier nader bezien en tevens wordt aangegeven hoe de verschillen de verklaring van de accountant kunnen beïnloeden.

\section{Nederland}

In de „Beschouwingen naar Aanleiding van de Wet op de Jaarrekening van Ondernemingen" (Beschouwingen), samengesteld door en onder verantwoordelijk. heid van de Commissies jaarverslaggeving van werkgevers- en werknemersorganisaties en het Nivra, wordt het onderwerp Onzekerheden en de vermelding daarvan in de jaarrekening voornamelijk aangeroerd in hoofdstuk IIIb bij de behandeling van voorzieningen. De tekst van de wet, Art. 2:329 B.W., spreekt met betrekking tot onzekerheden over een onder de passiva opgenomen bedrag ter vorming van een ,voorziening tegen risico's en verplichtingen, waarvan de omvang ten tijde van het opmaken van de balans nog niet nauwkeurig bekend is." De Beschouwingen, verder ingaand op het niet nauwkeurig bekend zijn van de risico's en verplichtingen, onderscheiden de volgende drie aspecten in onzeker. heden, n.l.

1 het al dan niet plaatsvinden van gebeurtenissen die het nadeel bestaande uit een verplichting tot betaling of een verloren gaan of waardevermindering van aktiva veroorzaken; 
2 het tijdstip waarop het nadeel zal worden geleden;

3 de omvang zelf van het nadeel.

Om uitdrukking te kunnen vinden d.m.v. een voorziening ofwel in de toelich. ting waar, binnen de structuur van de wet, vereiste informatie eveneens gegeven mag worden, dienen de volgende voorwaarden te bestaan met betrekking tot de onzekerheid:

a. er moeten risico's bestaan welke verbonden zijn aan bepaalde aktiva, passiva of bedrijfsaktiviteiten, welke risico's uitgaan boven het algemeen risico ver. bonden aan het ondernemen;

en

b. deze risico's moeten op balansdatum aanwezig zijn, d.w.z. zij vloeien voort uit gebeurtenissen, handelingen of verbintenissen van op of vóór de balansda. tum.

Indien de onzekerheid, uitgedrukt in een voorziening, betrekking heeft op de waardering van bepaalde aktiva wordt de voorziening als regel op het betreffen de aktief in mindering gebracht in de vorm van een waardecorrectie; vermelding van de voorziening in de balans of in de toelichting is niet vereist. In de overige gevallen worden onzekerheden ofwel onder passiva en in de toelichting ofwel al. leen in de toelichting vermeld. Voor het bepalen van de omvang waar dit rede. lijkerwijze mogelijk is, worden in de Beschouwingen een aantal methoden aan. gegeven. Waar een redelijke schatting niet mogelijk is wordt de voorkeur gegeven aan het alleen vermelden in de toelichting van de aard en (indien mogelijk) de maximale omvang van het risico.

Bovenstaande geeft in het kort weer hetgeen de opstellers van de jaarrekening dienen te vermelden met betrekking tot onzekerheden.

Bij zijn onderzoek naar de getrouwheid van de presentatie door middel van de jaarrekening dient de accountant ook te betrekken of de jaarrekening voldoet aan de wettelijke vereisten, zoals nader uitgewerkt in de Beschouwingen. Daarbij spe. len zowel de wijze waarop onzekerheden in de jaarrekening verwerkt zijn een rol als de vraag in hoeverre bij de accountant onzekerheden blijven bestaan.

De Gedrags- en Beroepsregels Registeraccountants GBR verwijzen in Art. 13 en Art. 14 naar onzekerheden. Een onderscheid wordt gemaakt tussen onzeker. heden die aan de goedkeurende strekking van de verklaring niet wezenlijk af. breuk doen, doch die van zodanig gewicht zijn dat zij in de verklaring tot uitdruk. king dienen te worden gebracht, en onzekerheden die van zodanige aard en om. vang zijn dat de accountant geen goed. of afkeurend oordeel omtrent de getrouw. heid van de jaarrekening als geheel kan uitspreken. In het eerste geval dient de accountant, met gebruikmaking van de woorden „onder voorbehoud" de onze. kerheden zodanig te omschrijven dat de draagwijdte ervan duidelijk blijkt, terwijl in het tweede geval de accountant de woorden ,geen oordeel omtrent de ge. trouwheid van de verantwoording als geheel" bezigt en tevens vermeldt omtrent welke aangelegenheden onzekerheid bestaat.

Wanneer de accountantsverklaring betrekking heeft op de jaarrekening welke op grond van Art. 2:309 B.W. getrouw en stelselmatig de grootte en de samen. stelling van vermogen en resultaat dient te geven, is het nodig vast te stellen of onzekerheden zodanig zijn dat zij al dan niet wezenlijk afbreuk doen aan de ge. trouwe weergave van het vermogen en het resultaat. De getrouwheid van zowel de grootte als van de samenstelling is het voorwerp van de jaarrekening. De ac- 
countantsverklaring heeft betrekking op de verantwoording als geheel (Art. 12 (1) G.B.R.). Wanneer derhalve onzekerheden bestaan ten aanzien van onderdelen van de jaarrekening dienen de te hanteren criteria voor de vaststelling van het al dan niet wezenlijk afbreuk doen toegepast te worden op de samenstellende on derdelen en niet alleen op het totaal beeld van de jaarrekening. Immers een on zekerheid van zodanige aard en omvang welke slechts in belangrijke mate het getrouwe beeld van de samenstelling en niet dat van de grootte van vermogen of resultaat beinvloedt is niettemin een afwijking van één van de eisen die aan de jaarrekening gesteld worden. Over het bepalen van „wezenlijk” en „,in belangrijke mate" worden richtlijnen gegeven in de Beschouwingen.

Bij het opstellen van de jaarrekening treden steeds onzekerheden op, inherent aan het maken van schattingen waarmee dit opstellen gepaard gaat. Het definitief bepalen wanneer zulke onzekerheden van zodanige aard en omvang zijn dat daardoor de getrouwheidsweergave beïnvloed wordt en wanneer zulks, vanwege het geringe belang, niet het geval is laat een grijs gebied over. Dit grijze gebied bestrijkt de omstandigheden waarin de accountant nog niet tot een afkeurende verklaring of oordeelonthouding komt. Hij geeft derhalve een goedkeurende ver. klaring af over de jaarrekening waarbij, in het kader van de rapporteringsvereisten of mogelijkheden voor de accountant, de onzekerheden waaraan hij in zijn verklaring refereert geen afbreuk doen aan de principiële inhoud en strekking van die (goedkeurende) verklaring. In de hierboven genoemde publikatie van het Nivra wordt het element van onzekerheid, en wel aangaande de continuïteitsmo. gelijkheid van de onderneming, aangeroerd. Bij ernstige onzekerheid over de continuïteit kan volgens de publikatie, indien onder bepaalde omstandigheden op going concern basis gewaardeerd wordt en de toelichting een toereikende uit. eenzetting over de continuiteitsproblematiek bevat, nog steeds een goedkeuren. de verklaring zonder voorbehoud van toepassing zijn, mits ondermeer de veron derstelling van de duurzame voortzetting speciaal vermeld wordt als een tussen paragraaf in de accountantsverklaring. Deze verklaring wordt een „voorwaardelijke verklaring" genoemd, en is tekstueel een goedkeurende verklaring met toe. voeging „bij deze veronderstelling”. In de meningsuiting wordt verder nog uiteengezet dat dit een normale goedkeurende verklaring blijft en in wezen gelijk is aan de Amerikaanse en Britse „subject to" verklaring (zie verderop). Opmerkelijk is dat het Nivra een alinea besteed heeft aan zijn visie over de toepasbaarheid van de "subject to" opinie in het Amerikaanse en Britse verkeer. Naar de mening van het Nivra zou het gebruik (door de Amerikanen en Britten?) van de „subject to" verklaring in situaties waarbij geen sprake is van ernstige onzekerheid omtrent de continuiteit niet juist zijn. Zoals hier verderop zal blijken wordt door het Ame. rikaanse en Engelse beroep inderdaad - en kennelijk terecht naar de mening van de beroepsbeoefenaars aldaar - de „subject to" verklaring gebruikt, zowel onder omstandigheden waarbij de (nieuwe) ,voorwaardelijke verklaring” door het Nivra aanbevolen wordt, als bij het zich voordoen van andere onzekerheden.

\section{Verenigde Staten}

In de literatuur en controle-richtlijnen met betrekking tot onzekerheden wordt gewezen op het bestaan daarvan, in het algemeen, bij het samenstellen van fi. nanciële verantwoordingen. Een onderscheid wordt gemaakt tussen algemene 
onzekerheden, in de vorm van schattingen, en die waarvan de uiteindelijke afloop zich moeilijk leent voor min of meer aanvaardbare schattingen. Wanneer deze laatste soort onzekerheden zich voordoet is het niet mogelijk om vast te stellen of en hoe de financiële verantwoording bijgesteld moet worden. De Amerikanen maken verder onderscheid tussen onzekerheden welke slaan op specifieke aangelegenheden waarvan de invloed op de verantwoording bepaald kan worden, zoals de mogelijke oninbaarheid van een belangrijke vordering, en die waarbij die invloed minder eenvoudig zodanig te identificeren is, zoals ernstige liquiditeits. problemen welke de voortzetting van de onderneming in gevaar kunnen brengen. Overigens wordt erkend dat het effect van de eerste groep onzekerheden eveneens desastreus kan zijn voor het voortbestaan van de onderneming. In beide gevallen dienen de aard en waar mogelijk de eventuele invloed van de onzeker. heden in de toelichting op de verantwoording vermeld te worden. De betreffende Amerikaanse literatuur behandelt apart de waarderingsgrondslagen-aspecten van onzekerheden in Statement of Financial Accounting Standards No. 5, „Accounting for Contingencies", (F.A.S.B. 5) en de controle technische aspecten in "Codification of Statements in Auditing Standards Numbers 1 to 7" paragraaf 509.21 e.v. Evenals dat gedaan is voor Nederland zullen op de eerste plaats in het kort de waarderingsgrondslagen behandeld worden waarna de Amerikaanse ac. countantsverklaring dienaangaande aan de orde komt.

F.A.S.B. 5 geeft een „range” aan waarbinnen de onzekerheden geplaatst kun. nen worden:

- waarschijnlijk - het is aannemelijk dat de toekomstige gebeurtenissen waarvan het nu nog onzekere verlies afhangt plaats zullen vinden

- onwaarschijnlijk - de kans dat de betreffende gebeurtenissen plaats vinden is vrij gering

- redelijkerwijze mogelijk - een situatie tussen beide voorgaande in.

Verslaglegging van onzekerheden dient als volgt te geschieden:

1 Een schatting van het verlies dient in de cijfers zelf verwerkt te worden wan. neer:

a. op grond van beschikbare inlichtingen vóór het afsluiten van de jaarreke. ning het waarschijnlijk is dat de betreffende gebeurtenis plaats zal vinden en $b$. het verlies geraamd kan worden.

2 Melding in de toelichting is vereist wanneer:

a. één van beide voorgaande elementen ontbreekt en

$b$. het redelijkerwijze mogelijk is dat een verlies zich zal voordoen.

Een toelichting kan ook vereist zijn in de eerste situatie indien zonder deze de opvoering van het geraamde verlies de jaarrekening misleidend zou maken. De toelichting vermeldt steeds de aard van de onzekerheid en geeft een schatting van het verlies ofwel het maximum van het verlies ofwel indien dat niet mogelijk is een vermelding van die onmogelijkheid.

Het opnemen in de toelichting van sommige onzekerheden, hoewel daarvan het eventuele verlies onwaarschijnlijk is zoals bijvoorbeeld bij verstrekte garanties ten behoeve van een op balansdatum verhaalbare debiteur, wordt niettemin eveneens voorgeschreven. Hier ook dient de aard (garantie) en het bedrag van de onzekerheid vermeld te worden.

De betrokkenheid van de accountant bij onzekerheden is volgtijdig aan die van de opstellers van de jaarrekening. Wanneer deze laatsten niet in staat zijn geweest 
een schatting te maken van de uitkomst van de gesignaleerde waarschijnlijke of redelijkerwijze mogelijke onzekerheden betekent dit nog niet dat het geen onderdeel van de funktie van de accountant is om te pogen wel zulk een schatting te maken. Indien de accountant van mening is dat het niet voor de hand ligt dat de afwikkeling van de onzekerheden een belangrijke invloed op de jaarrekening zal hebben kan hij een goedkeurende verklaring geven. Indien dit niet het geval is kan hij gebruik maken van ofwel een geclausuleerde verklaring (d.w.z. een ver. klaring onder voorbehoud met gebruikmaking van de woorden „except for" of "subject to") ofwel een oordeelonthouding.

Wanneer de accountant zich ervan heeft kunnen overtuigen dat de posten in de financiële verantwoording waarop de onzekerheden betrekking hebben, in overeenstemming met algemeen aanvaarde waarderingsgrondslagen gepresenteerd zijn, behoudens die aspecten waarop de onzekerheden slaan, kan hij een verklaring afgeven „onder voorbehoud" met betrekking tot en onder vermelding van die onzekerheden. Treden er naast de onzekerheidsproblemen nog andere afwijkingen op in waarderingsgrondslagen bij posten in de financiële verantwoor ding, dan gelden daarvoor onverkort de daartoe geëigende rapporteringsvereis ten zoals clausulering, afkeuring of oordeelonthouding.

De voorkeur wordt uitgesproken voor een geclausuleerde verklaring met gebruikmaking van de woorden „except for" of „,subject to”. De mogelijkheid van een oordeelonthouding wordt echter opengelaten, waarbij de accountant, zoals vereist bij alle oordeelonthoudingen, in een aparte alinea gemotiveerd aan moet geven waarom hij tot een oordeelonthouding besloten heeft.

Het is verder toegestaan om een ophelderende alinea te voegen tussen de „scope" alinea en de eigenlijke verklaring waarin bepaalde materies, met inbegrip van eventuele onzekerheden, wat meer nadruk krijgen. Wanneer van deze mogelijk heid gebruik gemaakt wordt dienen in de eigenlijke verklaring woorden zoals „met deze uitleg" vermeden te worden.

Inmiddels is recentelijk een exposure draft verschenen voor een Statement on Auditing Standards, welke zich verdiept in de accountantsverklaring wanneer zich omstandigheden voordoen waarbij onzekerheden bestaan ten aanzien van mogelijke verliezen voor een onderneming, die opgelost zullen worden wanneer één of meerdere gebeurtenissen al dan niet in de toekomst plaats zullen vinden. Hoe. wel een dergelijke exposure draft nog niet de status heeft van beslissende documentatie wordt daarmee toch wel aangegeven in welke richting de gedachten van het Amerikaanse beroep gaan. Welnu, deze exposure draft houdt zich aller. eerst bezig met de doelstelling van de financiële verantwoording namelijk dat, ge. baseerd op algemeen aanvaarde grondslagen, in de balans, winst en verliesre. kening en de toelichting, in voldoende mate met betrekking tot alle essentiële punten inlichtingen worden verschaft. Op grond van de FASB 5 (zie hierboven) zijn in voormelde staten en toelichting bepaalde omschrijvingen en uitleggingen vereist met betrekking tot de aard en de invloed van onzekerheden. Wanneer de accountant van oordeel is dat de betreffende onzekerheid in de jaarrekening in voldoende mate tot uitdrukking is gebracht en uitgelegd kan hij een goedkeuren de verklaring afgeven. Er bestaat geen principieel onderscheid in benadering bij onzekerheden in het algemeen en die welke bestaan bij continuïteitsproblemen. Slechts wanneer de accountant van mening is dat de voorziening voor en/of de toelichting op onzekerheden zowel in het algemeen als bij continuïteitsproble. 
men niet voldoet aan algemeen aanvaarde waarderingsgrondslagen dient hij een geclausuleerde of afkeurende verklaring af te geven.

\section{Verenigd Koninkrijk}

In de afwezigheid van formele uitspraken door het Schotse accountants instituut beperk ik mij tot de officiële literatuur van het Institute of Chartered Accountants in England and Wales. Het waarderingsgrondslagen-aspect van onzekerheden wordt, nogal summier, behandeld in Part 3 van Statement of Standard Accounting Practice 2 „Disclosure of Accounting Policies”. Wanneer een jaarrekening wordt opgesteld op een wijze welke in belangrijke mate afwijkt van de algemeen aanvaarde begrippen van voorzichtigheid en van continuiteit, wordt een uitleg voor zulk een afwijking vereist. De betreffende begrippen worden in Part 2 van de Statement nader als volgt gedefinieerd:

„the 'prudence' concept: revenue and profits are not anticipated, but are recog. nized by inclusion in the profit and loss account only when realised in the form either of cash or of other assets the ultimate cash realisation of which can be as. sessed with reasonable certainty; provision is made for all known liabilities (expenses and losses) whether the amount of these is known with certainty or is a best estimate in the light of the information available"

"the 'going concern' concept: the enterprise will continue in operational existence for the foreseeable future. This means in particular that the profit and loss account and balance sheet assume no intention or necessity to liquidate or curtail significantly the scale of operation"

Geen specifieke richtlijnen dus hoe te handelen bij onzekerheden in het algemeen of bij continuïteitsproblemen in het bijzonder. De externe accountant kan te rade bij de "Statements on Auditing”. Echter ook hier is weinig of niets dat zich rechtstreeks richt op de problematiek van onzekerheden. Statement on Auditing „Auditors' reports: forms and qualifications" (Members Handbook U 10) bevat een aantal opmerkingen en voorbeelden aan de hand waarvan de Britse accountant zijn standpunt kan bepalen. Een geclausuleerde verklaring is ondermeer op haar plaats wanneer de accountant van mening is dat de jaarrekening geen getrouw beeld geeft omdat, naar zijn mening, deze niet is opgesteld aan de hand van waarderingsgrondslagen vereist onder de omstandigheden. Die omstandigheden kun nen onzekerheden zijn met de daaruit resulterende gevolgen op de waarderingsgrondslagen. Een geclausuleerde verklaring is verder eveneens noodzakelijk wan. neer de accountant het niet eens is met het bedrag waarmee een aktief of passief op de balans of een opbrengst of uitgave in de winst. en verliesrekening voor. komt; d.w.z. bij verschil van mening over het bestaan en de invloed van onzeker. heden. Tenslotte kan een geclausuleerde verklaring nodig zijn wanneer de toelichting informatie geeft welke in tegenspraak is met de wijze van weergave van de situatie in de balans en winst en verliesrekening, bijvoorbeeld een onzekerheid wordt in de toelichting aangegeven terwijl de daaruit noodzakelijk voortvloeiende waarderingsgrondslag niet gehanteerd wordt.

Wanneer een geclausuleerde verklaring overwogen wordt dient de accountant eerst te beslissen of de betreffende zaken zo essentieel zijn dat de getrouwheid 
van het beeld in het gedrang komt en verder of hij het met de presentatie oneens is ofwel dat hij niet voldoende duidelijkheid heeft kunnen verkrijgen om tot een oordeel te komen. Indien het oneens zijn of de onduidelijkheid beperkt is, d.w.z. niet zo essentieel dat daardoor twijfel bestaat over het getrouwe beeld dat door de jaarrekening als geheel wordt opgeroepen, kan de accountant rapporteren dat de jaarrekening een getrouw beeld geeft onder het voorbehoud van bepaalde genoemde bedenkingen ofwel met nadergenoemde uitzonderingen. Aan de andere kant kunnen de onzekerheden voor de accountant zodanig zijn dat hij ofwel zich geen oordeel kan vormen over de jaarrekening ofwel, in uitzonderlijke omstandigheden, genoodzaakt is een afkeurende verklaring te geven.

Er kunnen zich de volgende situaties voordoen:

a. De accountant wordt geconfronteerd met een situatie waarbij er grote onzekerheid bestaat met betrekking tot een post welke zo belangrijk is dat daardoor de jaarrekening als geheel beïnvloed wordt en de getrouwheid van het beeld dat de jaarrekening oproept derhalve niet vastgesteld kan worden. De accountant rapporteert een dergelijke situatie door middel van een oordeel onthouding, onder vermelding van de omstandigheden.

Een voorbeeld uit de betreffende Statement on Auditing:

„Stocks stated at $€$. . . are located in (name of territory) and are at present un. realisable because they appear to have been sequestrated by the provisional Government. It is uncertain whether they will be realisable by the company at the amounts stated, if at all, and for this reason we are unable to form an opinion whether the accounts give a true and fair view etc..."

$b$. De accountant heeft niet alle inlichtingen kunnen krijgen die hij nodig meent te hebben met betrekking tot een post welke van minder belang is in het ge. heel van de jaarrekening. Hij dient dan in zijn verklaring zo duidelijk mogelijk weer te geven welke inlichtingen hem ontbreken en wat de daaruit voortvloeiende onzekerheid is. Een voorbeeld, eveneens uit de aangehaalde Statement on Auditing luidt:

„Some of the detailed stocktaking sheets relating to stocks held at the balance sheet date have been destroyed. In their absence we have been unable to substantiate the basis of computation of stock amounting to $E$... out of the total of $£ \ldots$ at which the stock is shown in the balance sheet.

Subject to the foregoing reservation the accounts in our opinion give a true and fair view etc..."

c. De accountant is van oordeel dat de onzekerheid zich zodanig zal ontwikkelen dat de invloed daarvan op de jaarrekening tegenstrijdig is met hetgeen door de directie daaromtrent daarin wordt gepresenteerd. Een afkeurende verkla. ring dient te volgen. De Statement on Auditing geeft als voorbeeld:

"The shares in PQLtd., which is in liquidation are shown in the balance sheet at their cost of $€$... but the liquidator has stated that it is unlikely that the com. pany will be able to pay its debts in full, with the consequence that the shares appear to be valueless. For this reason the accounts in our opinion do not give a true and fair view etc..."

De drie hierboven geschetste situaties kunnen als volgt toegepast worden in ge val van onzekerheden bij ondernemingen met continuïteitsproblemen:

a. Wanneer de toelichting aangeeft dat, hoewel het er op zou kunnen lijken dat voortzetting van de onderneming gevaar loopt, de directie niettemin van me. 
ning is dat dit gevaar niet zo groot is dat daardoor een waardering op going concernbasis misplaatst is, doch er zijn voor de accountant geen inlichtingen beschikbaar op basis waarvan de directie gemeend heeft toch een going concern basis te kunnen hanteren rapporteert hij:

"There is no information on the future financial support to or on profitable operations of the company. It is therefore uncertain if the company can continue and for this reason we are unable to form an opinion whether the accounts give a true and fair view etc..."

b. Wanneer in een vergelijkbare situatie er voor de accountant niet voldoende harde gegevens aanwezig zijn dat de continuïteit van een onderneming gewaarborgd is zou de Britse accountant als volgt kunnen rapporteren:

„In the absence of adequate information on the future financial support to or on profitable operations of the company we are unable to verify the propriety of the going concern basis used in the accounts as explained in note

Subject to the foregoing reservation the accounts, assuming future financial support to or profitable operations of the company, in our opinion give a true and fair view etc..."

c. Indien tenslotte de accountant duidelijke inlichtingen heeft dat de voortzetting van de onderneming niet meer mogelijk is en de jaarrekening niettemin op een going concern basis is opgesteld dan is ook van de Britse accountant een afkeurende verklaring vereist.

\section{Conclusie}

Bovenstaande bijzonderheden omtrent de opvattingen met betrekking tot verslaglegging en accountantsverklaringen bij onzekerheden geven aan dat er een aantal verschillen, soms zelfs essentiële, bestaan tussen de praktijk in Nederland, de Verenigde Staten en het Verenigd Koninkrijk. Ik heb gepoogd in bijlagen 1 en 2 schematisch de voornaamste verschillen weer te geven.

Het belang van het zich rekenschap geven van het bestaan en de invloed van deze verschillen doet zich voor bij financiële rapporteringen over de grenzen. Op grond van de duidelijkheid, welke een eerste vereiste is voor die rapportering zelf en de door de accountant gehanteerde tekst voor zijn verklaring, is extra aandacht hier geenszins overbodig.

\section{Literatuur}

- Meningsuiting van het College voor Beroepsvraagstukken: „de Inhoud van de Accountantsverklaring bij de Jaarrekening van Ondernemingen met Conti. nuïteitsproblemen"; Uitg. Nivra.

- Gedrags. en Beroepsregels Registeraccountants; Uitg. Nivra.

- Beschouwingen naar Aanleiding van de Wet op de Jaarrekening van Onder. nemingen; Uitg. Kluwer.

- Codification of Statements on Auditing Standards, numbers 1 to 7; Uitg. American Institute of Certified Public Accountants.

- Proposed Statement on Auditing Standards; Auditor's report when there are contingencies; Uitg. American Institute of Certified Public Accountants. 
- Statements of Financial Accounting Standards No. 5 „Accounting for Contin. gencies"; Uitg. Financial Accounting Standards Board.

- Statement of Standard Accounting Practice No. 2

„Disclosure of Accounting Policies”; Uitg. The Institute of Chartered Accoun. tants in England and Wales.

- Statement on Auditing No. 10; „Auditors' reports: forms and qualifications” Members Handbook U. 10; Uitg. The Institute of Chartered Accountants in England and Wales.

BIJLAGE 1

Verslaglegging bij onzekerheden

Onzekerheden betreffen aktiva, passiva of aktiviteiten en zijn aanwezig op balansdatum Redelijke schatting mogelijk van bovengenoemde onzekerheden Geen redelijke schatting mogelijk van bovengenoemde onzekerheden

\section{NL U.S.A. U.K.}

$1 \quad 1 \quad 1$

$2 \quad 3 \quad 2$

$4 \quad 4 \quad 4$

1 opvoeren in jaarrekening vereist

2 verwerking in balans of winst. en verliesrekening

3 verwerking in balans of winst-en verliesrekening alleen wanneer plaatsvinden van onzekerheid waarschijnlijk is; wanneer plaatsvinden redelijkerwijze mogelijk ofwel onwaarschijnlijk - zie 4

4 vermelding in toelichting:

NL: aard plus maximale omvang

U.S.A.: aard plus maximale omvang, ofwel vermelding dat dit laatste niet mogelijk is

U.K. aard. 


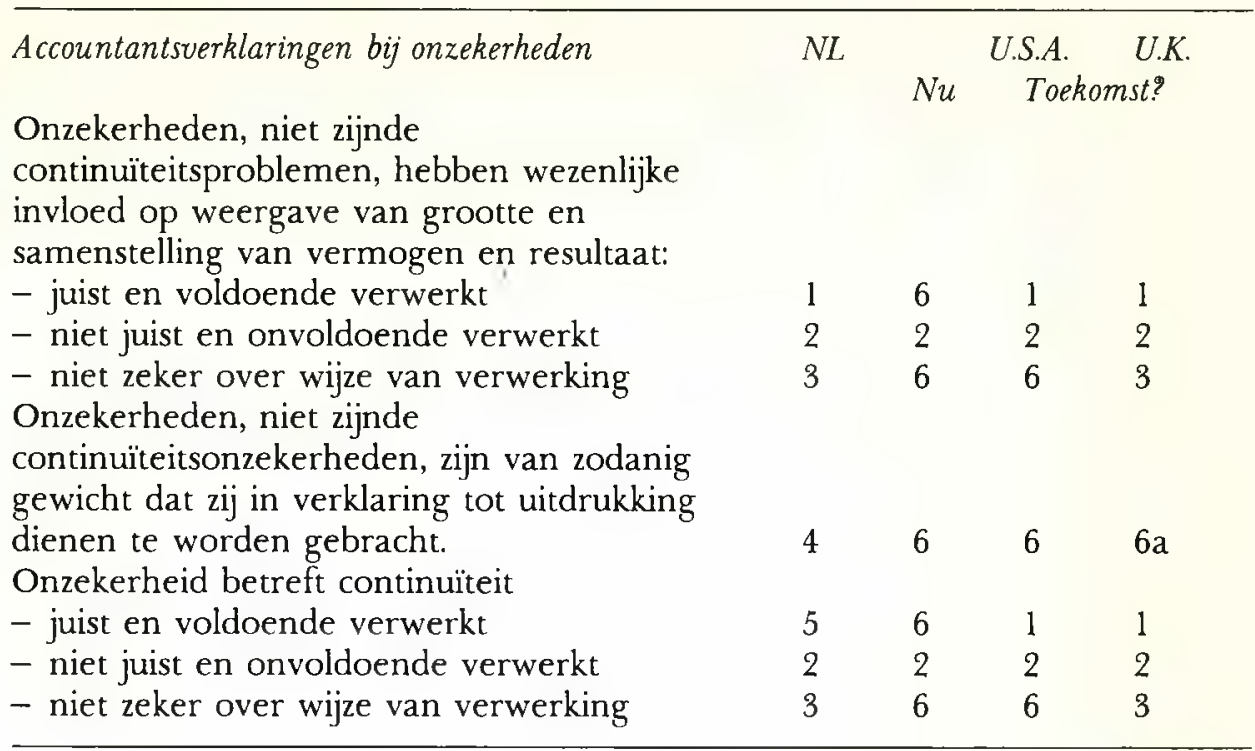

1 goedkeurende verklaring

2 afkeurende verklaring met vermelding van aard en betekenis van bedenking

3 oordeelonthouding met vermelding van onzekerheden

4 goedkeurende verklaring onder voorbehoud met duidelijke omschrijving draagwijdte onzekerheden

5 goedkeurende verklaring met uitleg-alinea inzake continuiteitsprobleem en verwijzing naar veronderstelling in eigenlijke verklaring

6a bij voorkeur geclausuleerde verklaring met vermelding onzekerheid in tussen-alinea en onder voorbehoud in eigenlijke verklaring, ofwel

b oordeelonthouding met vermelding onzekerheid in tussenalinea en motivering van onthouding in eigenlijke verklaring. 